\title{
Calprotectin: a novel biomarker for the diagnosis of pleural effusion
}

\author{
N Sánchez-Otero',3, S Blanco-Prieto',3, M Páez de la Cadena*, , L Vázquez-Iglesias', A Fernández-Villar², \\ MI Botana-Rial ${ }^{2}$ and FJ Rodríguez-Berrocal'
}

'Department of Biochemistry, Genetics and Immunology, Facultad de Biología, Universidad de Vigo, 36310 Vigo, Spain; ${ }^{2}$ Unit of Interventional Bronchopleural Pathology, Department of Pneumology, Complejo Hospitalario Universitario de Vigo (CHUVI), Vigo, Spain

BACKGROUND: Novel non-invasive biomarkers for the precise diagnosis of malignancy in pleural effusion (PE) are needed. The aim of this study was to determine the diagnostic accuracy of calprotectin for predicting malignancy in patients with exudative PE. METHODS: Calprotectin concentration was measured in 156 individuals diagnosed with exudative PE (67 malignant and 89 benign). Calprotectin accuracy for discriminating between malignant and benign PE was evaluated using receiver operating characteristic (ROC) curves. Univariate and multivariate logistic regression were performed to test the association between calprotectin levels and malignant PE. RESULTS: Calprotectin levels were significantly lower in malignant pleural fluid (257.2 $\mathrm{ng} \mathrm{ml}^{-1}$, range: 90.7-736.4) than benign effusions (2627. I ng ml ${ }^{-1}$, range: 2 I-9530. I). The area under the curve was 0.963 . A cutoff point of $\leqslant 736.4 \mathrm{ng} \mathrm{ml}^{-1}$ rendered a sensitivity of $100 \%$, with a specificity of $83.15 \%$, which could prove useful to delimit those patients with negative cytology tests that should be referred for more invasive diagnostic procedures. Logistic regression demonstrated a strong association between calprotectin and malignancy (adjusted OR 663.14).

CONCLUSION: Calprotectin predicts malignancy in pleural fluid with high accuracy and could be a good complement to cytological methods.

British Journal of Cancer (2012) 107, 1876-1882. doi:I0.1038/bjc.2012.478 www.bjcancer.com

Published online 23 October 2012

(c) 2012 Cancer Research UK

Keywords: malignant PE; diagnosis; accuracy; calprotectin

Pleural effusion (PE) can occur as a consequence of more than 50 recognised aetiologies and the distinction between benign $\mathrm{PE}$ (BPE) and PE of malignant origin (MPE) remains a diagnostic challenge. Most MPEs (90-97\%) (Heffner, 2008) are exudates, that is, they occur due to an increased extravasation of the pleural vessels. The presence of MPE can be observed as a complication of nearly all malignancies, most frequently lung and breast cancers, whereas pneumonic and tuberculous infections are the leading causes of BPE (Neragi-Miandoab, 2006; Villena-Garrido et al, 2006; Roberts et al, 2010).

The initial diagnostic approach for exudative PE includes semiinvasive methods, such as thoracocentesis, to allow the cytological, microbiological, and biochemical examination of the fluid (Hooper et al, 2010). Cytological analysis of the pleural fluid is the most common method for establishing malignancy (Villena-Garrido et al, 2006; Hooper et al, 2010). Unfortunately, while the specificity of cytological findings is $100 \%$, only $60 \%$ of malignant effusions can be diagnosed cytologically (Alemán et al, 2007; Hooper et al, 2010). For undiagnosed exudative effusions with suspicion of malignancy but negative cytology, more invasive techniques are necessary (Hooper et al, 2010). Closed pleural biopsy has small additive diagnostic value, and thoracoscopy is the preferred method because it is diagnostic in $<90 \%$ of patients (Light, 2006; Villena-Garrido et al, 2006; Roberts et al, 2010).

\footnotetext{
*Correspondence: Professor M Páez de la Cadena; E-mail: mpaez@uvigo.es ${ }^{3}$ These authors contribute equally to this work.

Received I June 2012; revised 20 September 2012; accepted 26 September 2012; published online 23 October 2012
}

Nevertheless, this invasive procedure may not be available at all facilities (Hooper et al, 2010).

Many studies have evaluated the ability of tumoural markers (reviewed in Gu et al, 2007; Liang et al, 2008) and other biomarkers to improve the diagnosis of MPE (Dikmen et al, 2003; Duysinx et al, 2008; Botana-Rial et al, 2011). Panels combining different markers have also been proposed (Porcel et al, 2004; Kremer et al, 2010). Disappointingly, none have shown sufficient sensitivity and specificity to be considered a candidate diagnostic marker of MPE (Hooper et al, 2010).

In a previous work, we employed a proteomic approach to search for non-invasive markers of lung cancer in PE (RodríguezPiñeiro et al, 2010). We found several proteins that were differentially expressed in MPE (pleural fluid from patients with non-small-cell lung cancer) vs BPE (pleural fluid from patients with tuberculosis). Among these, the calcium-related proteins S100-A8 and S100-A9 (which form the non-covalent heterodimer calprotectin) were expressed in lower quantities in MPE than BPE.

In the present study, we demonstrated that calprotectin can be measured by a specific immunoquantitative enzyme-linked immunosorbent assay (ELISA) in the pleural fluid and that this method is useful for discriminating between MPE and BPE.

\section{METHODS}

\section{Study population}

A total of 156 consecutive non-selected patients with a specific diagnosis for exudative $\mathrm{PE}$ were enrolled in this prospective study. 
Patients were admitted from April 2007 to December 2010 at the Department of Pneumology, Complejo Hospitalario Universitario de Vigo (CHUVI). The study was approved by the Galician Ethical Committee for Clinical Research (200/179), and all participants provided written informed consent.

\section{Pleural fluid diagnosis}

The PE diagnosis protocol followed the recommendations of different international societies (Villena-Garrido et al, 2006; Hooper et al, 2010) and has been employed in previous studies by our group (Botana-Rial et al, 2011). Patients with PE observed via $\mathrm{X}$-ray or thoracic computerised tomography were submitted to the Bronchopleural Pathology Unit. Achievement of diagnosis without the need of performing a thoracocentesis was considered as an exclusion criterion; therefore, from 169 patients initially recruited, 13 were excluded and 156 were eligible for the study. After detailed history and examination, an initial thoracocentesis for common biochemical, microbiological, and cytological studies was performed. Thoracocentesis classified the effusion as transudate or exudate. Subsequent tests and patient management protocols were selected based on the diagnosis. If the test did not yield a diagnosis and the aetiology of the exudates remained unidentified, a second thoracocentesis and/or a transparietal pleural biopsy were conducted. Depending on the diagnostic suspicion, complementary tests were recommended (e.g., fibrobronchoscopy or autoimmunity studies). Patients in whom the cause of PE had not yet been identified after the aforementioned methods were submitted to medical or surgical thoracoscopy; in other patients, clinical and radiological follow-up for at least 1 year was undertaken to confirm the resolution of symptoms or recurrence of PE.

Before the beginning of any treatment, the biochemical parameters of the pleural fluid (differential cell counts, $\mathrm{pH}$, proteins, lactate dehydrogenase, glucose, and adenosine deaminase (ADA)) were analysed.

The aetiology of PE was determined based on accepted criteria as described by the Spanish Society for Pneumology and Thoracic Surgery (Villena-Garrido et al, 2006). Two principal groups (MPE and BPE) were established for analysis. Malignant origin was defined when malignant cells were identified upon cytological or histological examination or in a biopsy specimen. Malignant origin cases were divided into three subgroups according to the PE aetiology: epithelial-origin neoplasias, mesotheliomas, and lymphomas. Patients with BPE were divided into five subgroups: tuberculous, parapneumonic, miscellaneous, paramalignant, and nonneoplastic of unknown origin. The diagnosis of tuberculous PE was based on the presence of positive stain or culture for Mycobacterium tuberculosis in the pleural fluid, sputum, or pleural biopsy or the presence of typical caseating granulomas in the pleural biopsy. Any $\mathrm{PE}$ associated with pneumonia and response to antibiotics was classified as parapneumonic effusion. The miscellaneous group included PE that fulfilled the specific criteria for the diagnosis of $\mathrm{PE}$ of diverse origin (post-surgery, chylothorax, secondary to collagen vascular disease, secondary to drug reactions, Dressler's syndrome, uraemic pleuritis, post-trauma, or ovarian hyperstimulation syndrome). Paramalignant PE refers to effusions caused by the indirect effects of cancer on the pleural space or the pleural effects of cancer radiation or drug therapy (Heffner, 2008). Non-neoplastic PE of unknown origin was defined as PE comprising non-specific pleuritis observed at thoracoscopy, thoracotomy, biopsy, or autopsy, or the absence of symptoms or recurrence of PE within 1-year clinical and radiological follow-up (Villena et al, 2003).

\section{PE sampling}

Pleural fluid samples $(5 \mathrm{ml})$ were obtained, centrifuged at $800 \mathrm{~g}$ for $15 \mathrm{~min}$ and immediately frozen in $0.5 \mathrm{ml}$ aliquots at $-20^{\circ} \mathrm{C}$.

\section{Biochemical procedures}

Calprotectin levels were determined using a sandwich ELISA from Hycult Biotechnology (Uden, The Netherlands). The laboratory calprotectin test was conducted completely independently of clinical diagnosis and treatment. The assay was conducted according to the manufacturer's guidelines.

\section{Statistical analysis}

Normal distribution and homogeneity of variances were checked using the Kolmogorov-Smirnov and Levene tests, respectively. Calprotectin levels distributed normally in the groups under study, but variances were not homogeneous. Analyses were conducted with non-parametric tests: differences between two independent samples were assessed with Mann-Whitney $U$-test, and multiple comparisons were made with Kruskal-Wallis test.

The accuracy of calprotectin levels for discriminating MPE from BPE was evaluated using receiver operating characteristic (ROC) curves. Sensitivity, specificity, accuracy, positive predictive values (PPVs), negative predictive values (NPVs), and likelihood ratios (LRs) and their corresponding confidence intervals (CIs) were calculated. Univariate logistic regression was performed to test the association between calprotectin levels and the presence of MPE. This relationship was also examined for other variables: patient characteristics (sex, age, smoking status, and existence of previous neoplasia) and selected PE markers (size of PE, differential cell counts, $\mathrm{ADA}$, and protein content). Unadjusted ORs, calculated as an estimate of the relative risk, and the corresponding 95\% CIs were reported. Significant predictors in the univariate analysis $(P<0.1)$ were entered into a multivariate logistic regression model to assess the independent predictive value of calprotectin levels.

To correct for possible overfitting and thus avoid an excessively optimistic assessment of marker performance in the correct classification of patients provided by the original ROC curve, the leave-one-out cross-validation (LOOCV) method was used to derive a cross-validated ROC curve and area under the ROC curve (AUC). The comparison between the original and cross-validated AUCs represents an internal validation measure of the fitting.

All statistical analyses were performed with SPSS version 15.0 (SPSS Inc., Chicago, IL, USA). A $P$-value $<0.05$ was considered statistically significant. The data validation was conducted in $\mathrm{R}$ using the stats (for fitting logistic generalised linear models) and ROCR (for constructing ROC curves and AUCs) packages. The sensitivity, specificity, PPV, NPV, and LR were calculated using MedCalc version 11.5.1 (MedCalc Software, Mariakerke, Belgium).

\section{RESULTS}

\section{Patient characteristics}

The calprotectin levels in the pleural fluid of 156 consecutive patients with a specific diagnosis of exudative PE were analysed. The patients were grouped for statistical analysis according to the diagnostic criteria described in the Methods section, as summarised in Table 1 .

\section{Calprotectin levels in PE}

Table 2 presents the PE calprotectin concentrations expressed as $\mathrm{ng} \mathrm{ml}{ }^{-1}$ in the different diagnostic groups. The mean calprotectin level of the whole MPE group was $257.2 \mathrm{ng} \mathrm{ml}^{-1}$, significantly lower $(P<0.001$, Mann-Whitney $U$-test $)$ than that of the BPE patients $\left(2627.1 \mathrm{ng} \mathrm{ml}^{-1}\right)$. Among the MPE groups, there were also substantial differences in calprotectin levels $(P=0.08$, KruskalWallis test) between the patients with epithelial-origin neoplasias and those with mesothelioma $\left(238.7 \mathrm{ng} \mathrm{ml}^{-1}\right.$ vs $435.8 \mathrm{ng} \mathrm{ml}^{-1}$, $P=0.03$, Mann-Whitney $U$-test). 
Table I Demographic data for the total study population

\begin{tabular}{|c|c|c|c|}
\hline PE origin & $\begin{array}{l}\text { No. of } \\
\text { patients }\end{array}$ & $\begin{array}{l}\text { No. of men/ } \\
\text { women }\end{array}$ & $\begin{array}{l}\text { Age, years } \\
\text { mean } \pm \text { s.d. }\end{array}$ \\
\hline MPE & 67 & $42 / 25$ & $67 \pm 13.9$ \\
\hline Epithelial-origin neoplasias & 58 & $32 / 26$ & $68 \pm 13.1$ \\
\hline NSCLC & 42 & $31 / 11$ & $68 \pm 13.4$ \\
\hline Breast cancer & 6 & $0 / 6$ & $63 \pm 16.0$ \\
\hline SCLC & 3 & $2 / 1$ & $75 \pm 5.3$ \\
\hline Ovarian cancer & 2 & $0 / 2$ & $82 \pm 4.2$ \\
\hline Thymic epithelial neoplasm & 2 & $0 / 2$ & $69 \pm 5.7$ \\
\hline Gastric cancer & 2 & $0 / 2$ & $73 \pm 18.4$ \\
\hline Cholangiocarcinoma & 1 & $1 / 0$ & 61 \\
\hline Mesothelioma & 6 & $5 / 1$ & $67 \pm 11.6$ \\
\hline Lymphoma & 3 & $3 / 0$ & $55 \pm 31.0$ \\
\hline BPE & 89 & $61 / 28$ & $53 \pm 20.7$ \\
\hline Tuberculosis & 30 & $20 / 10$ & $44 \pm 23.4$ \\
\hline Parapneumonic & 29 & $22 / 7$ & $55 \pm 17.1$ \\
\hline Miscellaneous & 12 & $8 / 4$ & $57 \pm 18.9$ \\
\hline After surgery & 3 & $2 / 1$ & $64 \pm 10.5$ \\
\hline Chylothorax & 2 & $2 / 0$ & $62 \pm 11.3$ \\
\hline $\begin{array}{l}\text { Secondary to collagen } \\
\text { vascular diseases }\end{array}$ & 2 & $2 / 0$ & $48 \pm 15.6$ \\
\hline Secondary to drug reaction & 1 & $1 / 0$ & 24 \\
\hline Dressleŕs syndrome & 1 & $1 / 0$ & 80 \\
\hline Uraemic pleuritis & 1 & $0 / 1$ & 45 \\
\hline After trauma & 1 & $0 / 1$ & 83 \\
\hline $\begin{array}{l}\text { Ovarian hyperstimulation } \\
\text { syndrome }\end{array}$ & 1 & $0 / 1$ & 34 \\
\hline Paramalignant & 3 & $2 / 1$ & $65 \pm 21.7$ \\
\hline $\begin{array}{l}\text { Non-neoplastic of unknown } \\
\text { origin }\end{array}$ & 15 & $10 / 5$ & $62 \pm 18.0$ \\
\hline
\end{tabular}

Abbreviations: $\mathrm{BPE}=$ benign $\mathrm{PE} ; \mathrm{MPE}=$ malignant $\mathrm{PE} ; \mathrm{NSCLC}=$ non-small cell lung cancer; $\mathrm{PE}=$ pleural effusion; $\mathrm{SCLC}=$ small cell lung cancer.

For BPE patients, there were also statistically significant differences between clinical types $(P<0.001$, Kruskal-Wallis test). The calprotectin levels in the $\mathrm{PE}$ of tuberculous patients $\left(2982.3 \mathrm{ng} \mathrm{ml}^{-1}\right)$ were significantly higher $(P<0.01$, MannWhitney $U$-test) than those of patients classified as miscellaneous $\left(1654.8 \mathrm{ng} \mathrm{m}^{-1}\right)$ or non-neoplastic of unknown origin (1234.1 $\mathrm{ng} \mathrm{ml}^{-1} ; P<0.001$, Mann-Whitney $U$-test). Patients suffering from pneumonia expressed the highest levels of calprotectin $\left(3517.9 \mathrm{ng} \mathrm{ml}^{-1}\right)$, but these levels were not significantly different from those in the tuberculous group. However, they were significantly higher than those of the miscellaneous $(P=0.02$, Mann-Whitney $U$-test) and non-neoplastic of unknown origin $(P<0.01$, Mann-Whitney $U$-test $)$ groups.

\section{Calprotectin prediction of MPE}

We also evaluated the diagnostic performance of calprotectin to determine its utility in differentiating PE origin. Figure 1A shows the ROC curve for the discrimination of patients with MPE $v s$ BPE. The AUC of calprotectin was found to be 0.963 (95\% CI, 0.932 0.994). The LOOCV method produced a cross-validated AUC of 0.957 (0.931-0.989). Figure 1B shows the individual concentrations of calprotectin in the different diagnostic groups.

Table 3 shows the specificity, sensitivity, PPV, NPV, positive, and negative LRs, and accuracy data. We explored the ability of calprotectin to distinguish MPE from BPE by establishing two cutoff points. The first cutoff point, $\leqslant 545 \mathrm{ng} \mathrm{ml}^{-1}$, was selected because it presented the greatest accuracy (92.31\%), with a sensitivity of $97.01 \%$ and specificity of $88.76 \%$. We also established a cutoff point of $\leqslant 736.4 \mathrm{ng} \mathrm{ml}^{-1}$ for a sensitivity of $100 \%$, with a high specificity $(83.15 \%)$ but a slightly lower accuracy $(90.38 \%)$.
Table 2 Concentration of calprotectin in pleural fluid

\begin{tabular}{|c|c|c|c|}
\hline PE origin & $\begin{array}{l}\text { No. of } \\
\text { patients }\end{array}$ & $\begin{array}{c}\text { Calprotectin, } \\
\text { ng ml } \mathbf{l}^{-1} \\
\text { mean } \pm \text { s.d. }\end{array}$ & $P$-value \\
\hline MPE & 67 & $257.2 \pm 134.4$ & \\
\hline Epithelial-origin neoplasias & 58 & $238.7 \pm 112.1^{\dagger}$ & \\
\hline NSCLC & 42 & $255.4 \pm 115.3$ & \\
\hline Breast cancer & 6 & $163.6 \pm 92.1$ & \\
\hline $\mathrm{SCLC}$ & 3 & $239.5 \pm 142.0$ & \\
\hline Ovarian cancer & 2 & $183.8 \pm 128.0$ & \\
\hline Thymic epithelial neoplasm & 2 & $242.9 \pm 65.8$ & \\
\hline Gastric cancer & 2 & $|54| \pm 25.1$. & \\
\hline Cholangiocarcinoma & I & 238.6 & \\
\hline Mesothelioma & 6 & $435.8 \pm 225.6$ & \\
\hline Lymphoma & 3 & $258.8 \pm 72.7$ & \\
\hline$B P E$ & 89 & $2627.1 \pm 2182.1^{\ddagger}$ & \\
\hline Tuberculous & 30 & $2982.3 \pm 1573.0^{\S, \|}$ & \\
\hline Parapneumonic & 29 & $3517.9 \pm 2852.8^{* * *, \dagger \dagger}$ & \\
\hline Miscellaneous & 12 & $1654.8 \pm 1536.4$ & \\
\hline After surgery & 3 & $763.6 \pm 357.6$ & \\
\hline Chylothorax & 2 & $679.1 \pm 221.3$ & \\
\hline $\begin{array}{l}\text { Secondary to collagen } \\
\text { vascular diseases }\end{array}$ & 2 & $4562.5 \pm 1621.5$ & \\
\hline $\begin{array}{l}\text { Secondary to drug } \\
\text { reaction }\end{array}$ & I & | 169.2 & \\
\hline Dressleŕs syndrome & I & 1415.6 & \\
\hline Uraemic pleuritis & I & 572.58 & \\
\hline After trauma & I & 2265.5 & \\
\hline $\begin{array}{l}\text { Ovarian hyperstimulation } \\
\text { syndrome }\end{array}$ & I & 1660.9 & \\
\hline Paramalignant & 3 & $1316.9 \pm 1006.6$ & \\
\hline $\begin{array}{l}\text { Non-neoplastic of unknown } \\
\text { origin }\end{array}$ & 15 & $1234.1 \pm 1164.4$ & \\
\hline
\end{tabular}

Abbreviations: $\quad \mathrm{BPE}=$ benign $\mathrm{PE} ; \mathrm{MPE}=$ malignant $\mathrm{PE} ; \quad \mathrm{NSCLC}=$ non-small cell lung cancer; $\mathrm{PE}=$ pleural effusion; $\mathrm{SCLC}=$ small cell lung cancer. ${ }^{\dagger} P=0.03$ vs mesothelioma (Mann-Whitney U-test). ${ }^{\ddagger} P<001$ among BPE groups (Kruskal-Wallis test). ${ }^{\circledR} P<0$ I vs miscellaneous (Mann-Whitney $U$-test). ${ }^{\|} P<00$ I vs non-neoplastic of unknown origin (Mann-Whitney U-test). ${ }^{* *} P=0.02$ vs miscellaneous (Mann-Whitney U-test). ${ }^{\dagger} P<0.01$ vs non-neoplastic of unknown origin (Mann-Whitney U-test). ${ }^{\dagger \dagger} P<0.00$ I MPE vs BPE (Mann-Whitney U-test).

In addition, we analysed the ability of calprotectin to distinguish PE subtypes. The marker showed the highest accuracy in discriminating MPE from PE of tuberculous and parapneumonic origin (97.94\% and $95.83 \%$, respectively) (Table 3). Receiver operating characteristic curves corresponding to the data in Table 3 are provided as Supplementary Figure S1.

\section{Influence of calprotectin levels on MPE prediction}

Logistic regression was performed with a cutoff of $\leqslant 545 \mathrm{ng} \mathrm{ml}^{-1}$. The OR for the cutoff $\leqslant 736.4 \mathrm{ng} \mathrm{ml}^{-1}$ cannot be reported because the observed $100 \%$ sensitivity produces sampling zeroes, which affect the maximum likelihood estimates of the parameters in the logistic regression model. Univariate logistic regression demonstrated a strong association between the low levels of calprotectin and malignancy (Table 4), with a high unadjusted OR (256.75, $P<0.001)$. Univariate analysis also revealed significant associations between MPE and patient age, smoking status, size of PE, cell count status, ADA, and protein levels. The significant predictors were entered into a multivariate logistic regression model, indicating that the association between low calprotectin levels and MPE did not depend on any of the other variables, and calprotectin levels $\leqslant 545 \mathrm{ng} \mathrm{ml}^{-1}$ remained a unique significant predictor, with an adjusted OR of $663.14(P<0.001)$. 
A
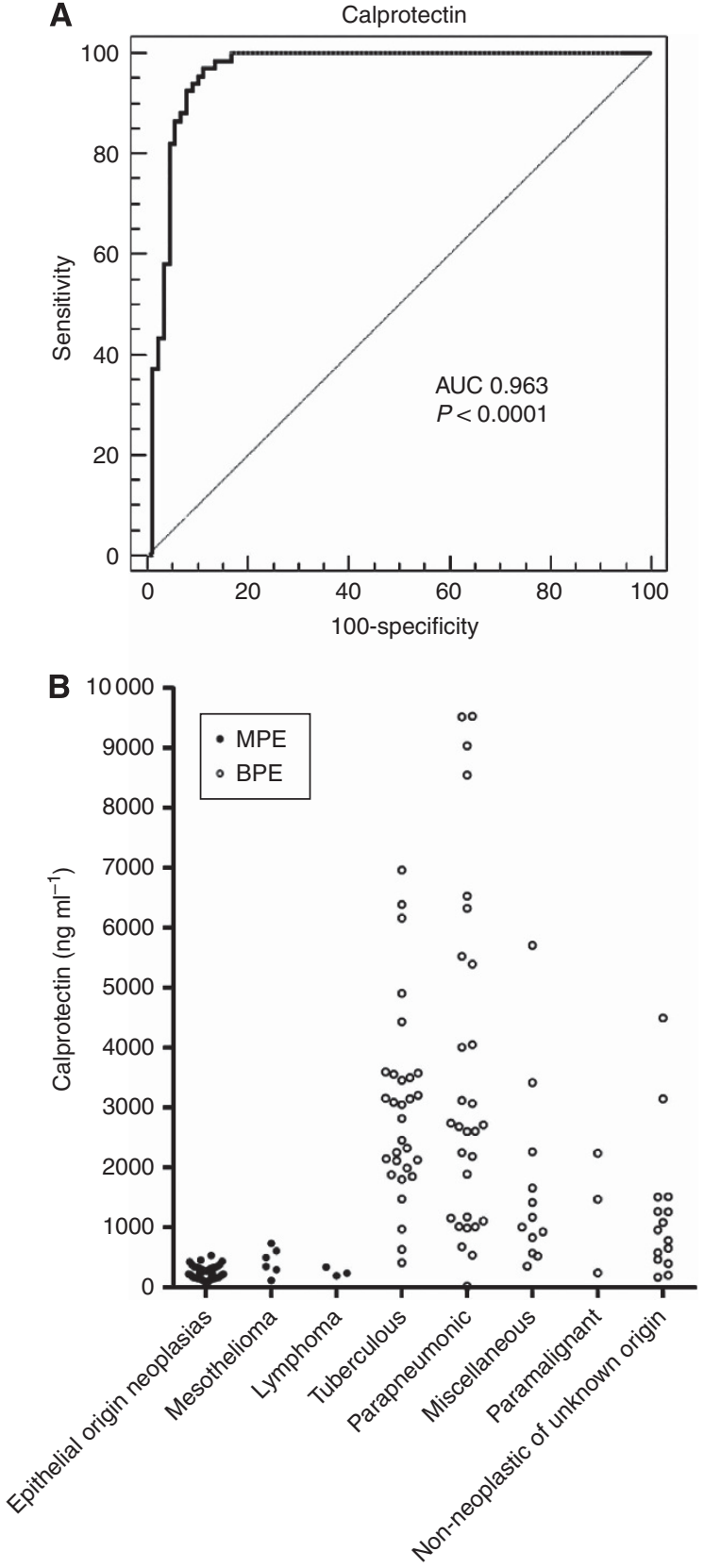

Figure I Calprotectin ROC curve and levels in MPE and BPE samples. (A) Non-parametric ROC curve for calprotectin assay results in distinguishing between MPE and BPE patients. (B) Individual PE calprotectin levels in patients with neoplasias (epithelial neoplasias, mesothelioma, and lymphoma) and benign infections (tuberculosis, pneumonic, miscellaneous, paramalignant and non-neoplastic of unknown origin).

\section{DISCUSSION}

The present work is the first study to evaluate the utility of calprotectin as a biomarker for exudative PE diagnosis. We searched for new non-invasive biomarkers to aid in the discrimination between BPE and MPE because current clinical procedures require an invasive approach in many cases.

Mean calprotectin levels were 10 -fold lower in malignant effusions than benign effusions $(P<0.001)$. The mean concentration values were similar among the cancer types evaluated, with the exception of mesothelioma. In addition, patients with BPE also showed differences in calprotectin concentration, with tuberculous and parapneumonic patients having the highest values.

To date, studies regarding the presence of calprotectin in malignant effusions are scarce. Davidson et al (2010) reported calprotectin levels ranging from 301 to $9431 \mathrm{ng} \mathrm{ml}^{-1}$ in 36 female breast cancer patients. Our results are not directly comparable to these results because that group analysed a combination of pleural, peritoneal, and pericardial effusions. In PEs of patients with advanced-stage ovarian carcinoma (Odegaard et al, 2008), Odegaard et al (2008) described a range from 2008 to $3335 \mathrm{ng} \mathrm{ml}^{-1}$ calprotectin, which is much greater than the range observed here, although it should be noted that our study included only two PE from ovarian tumour patients. Furthermore, it is important to note that both of the previous studies used a different ELISA assay, and discrepancies in protein concentration calculations could arise when using different antibodies (Kristinsson et al, 1998).

The analysis of diagnostic performance showed a good ability to distinguish between MPE and BPE, with an AUC of 0.963. Two cutoff points were established: $\leqslant 545 \mathrm{ng} \mathrm{ml}^{-1}$ to achieve maximum accuracy, with a sensitivity and specificity of $97.01 \%$ and $88.76 \%$, respectively, and $\leqslant 736.4 \mathrm{ng} \mathrm{ml}^{-1}$ to achieve a sensitivity of $100 \%$, although this involved a moderate decrease in specificity (to $83.15 \%)$.

This great diagnostic accuracy allows the correct classification of MPEs that may be misdiagnosed with cytology. Whatever the cutoff employed, this assay significantly enhances the sensitivity of MPE diagnosis over cytology alone. In our study, among the 67 patients with malignancy, 34 patients had a positive pleural cytology test in the first thoracocentesis, whereas 33 patients had negative cytology; thus, the sensitivity of cytology was $50.75 \%$. The addition of the calprotectin assay with a cutoff of $\leqslant 545 \mathrm{ng} \mathrm{ml}^{-1}$ accurately identified 31 of the 33 cytology-negative MPE patients. The second cutoff point proposed, $\leqslant 736.4 \mathrm{ng} \mathrm{ml}^{-1}$, correctly classified all negative cytology MPE patients.

Thus, the calprotectin assay with the $100 \%$ sensitivity cutoff could be included as an additional test to complement cytology for the diagnostic management of suspected malignant effusions (see Supplementary Figure S2, modified from Sriram et al (2011)). In the present study, 169 patients with PE were initially recruited, but, as explained in Methods, 13 patients were diagnosed without requiring further tests or using different tests rather than analysis of the pleural fluid. The remaining 156 patients with a PE, after history evaluation and clinical examination, were initially submitted to thoracocentesis that allows the biochemical, microbiological, and cytological study of the fluid. The cytology results would determine whether calprotectin should be measured. Positive cytological tests diagnose malignancy. In our study 34 of our 67 MPE patients were confirmed with this test; thus, calprotectin measurement would be unnecessary. Remarkably, the cytology test provided negative results for the remaining 122 individuals, which included 33 patients with MPE and 89 patients with BPE. For the patients with negative cytology tests, calprotectin could be measured, and the results would indicate the appropriate future studies. The number of patients that might benefit from further invasive procedures would thus be limited to those presenting levels below the cutoff, that is, all 33 of the malignant patients with negative cytology and 15 BPE patients (16.85\% of BPE) in whom a diagnosis of malignancy could not be discarded. In these patients, a percutaneous pleural biopsy or thoracoscopy are required to obtain a definitive diagnosis. Conversely, malignancy was excluded in 74 of the 89 BPE subjects in the study with effusions with calprotectin levels above the cutoff, corresponding to benign conditions; among these patients, pleural biopsy is only advised in selected cases, such as in patients with suspected tuberculous PE.

Additionally, the sensitivity and specificity of the calprotectin assay for the diagnosis of MPE greatly surpassed those presented by classical PE markers, such as CEA, CA-125, CYFRA 21-1, and 
Table 3 Cutoff, sensitivity, specificity, predictive values, $L R+, L R-, C l$ and accuracy for calprotectin in classifying different PE groups

\begin{tabular}{|c|c|c|c|c|c|c|c|}
\hline Group and cutoff & $\begin{array}{l}\text { Sensitivity \% } \\
(95 \% \mathrm{Cl})\end{array}$ & $\begin{array}{c}\text { Specificity \% } \\
\text { (95\% Cl) }\end{array}$ & $\begin{array}{c}\text { PPV \% } \\
(95 \% \mathrm{CI})\end{array}$ & $\begin{array}{l}\text { NPV \% } \\
(95 \% \text { Cl) }\end{array}$ & $\begin{array}{c}\text { Positive LR } \\
\text { (95\% Cl) }\end{array}$ & $\begin{array}{l}\text { Negative LR } \\
(95 \% \mathrm{Cl})\end{array}$ & Accuracy \\
\hline $\begin{array}{l}\text { MPE vs BPE } \\
\leqslant 545 \mathrm{ng} \mathrm{ml}^{-1}\end{array}$ & 97.01 (89.6-99.6) & $88.76(80.3-94.5)$ & 86.7 (76.8-93.4) & 97.5 (91.3-99.7) & $8.63(7.9-9.4)$ & $0.034(0.008-0.1)$ & 92.3 \\
\hline $\begin{array}{l}\text { MPE vs BPE } \\
\leqslant 736.4 \mathrm{ng} \mathrm{ml}^{-1}\end{array}$ & $100(94.6-100)$ & 83.15 (73.7-90.2) & $81.7(71.6-89.4)$ & $100(95.1-100)$ & $5.93(5.4-6.5)$ & 0 & 90.4 \\
\hline $\begin{array}{l}\text { MPE vs BPE subgroup I } \\
\leqslant 455.4 \mathrm{ng} \mathrm{ml}^{-1}\end{array}$ & 92.54 (83.4-97.5) & $83.33(65.3-94.4)$ & $92.5(83.3-97.6)$ & $83.3(65.3-94.4)$ & $5.55(4.7-6.6)$ & $0.09(0.03-0.3)$ & 89.7 \\
\hline $\begin{array}{l}\text { MPE vs Parapneumonic } \\
\leqslant 532.5 \mathrm{ng} \mathrm{ml}^{-1}\end{array}$ & $95.52(87.5-99.1)$ & 96.55 (82.2-99.9) & $98.5(91.6-100)$ & $90.3(74.2-98.0)$ & $27.7(25.4-30.2)$ & $0.05(0.005-0.4)$ & 95.8 \\
\hline $\begin{array}{l}\text { TB vs subgroup I } \\
\leqslant 1660.9 \mathrm{ng} \mathrm{ml}^{-1}\end{array}$ & $86.67(69.3-96.2)$ & $80(61.4-92.3)$ & $85.7(63.2-92.9)$ & $81.2(66.9-96.1)$ & $4.33(3.5-5.4)$ & $0.17(0.05-0.5)$ & 83.3 \\
\hline
\end{tabular}

Abbreviations: $\mathrm{BPE}=$ benign $\mathrm{PE} ; \mathrm{Cl}=$ confidence interval; $\mathrm{LR}=$ likelihood ratio; $\mathrm{MPE}=$ malignant $\mathrm{PE} ; \mathrm{NPV}=$ negative predictive value; $\mathrm{PE}=$ pleural effusion; $\mathrm{PPV}=$ positive predictive value; TB = tuberculosis. BPE subgroup I: Miscellanea, paramalignant, and non-neoplastic of unknown origin PE.

Table 4 Results of the univariate and multivariate logistic regression analysis of demographic characteristics and selected markers

\begin{tabular}{|c|c|c|c|c|}
\hline Characteristics & Univariate analysis OR $(95 \% \mathrm{Cl})$ & $P$-value & Multivariate analysis OR $(95 \% \mathrm{Cl})$ & $P$-value \\
\hline Age $\geqslant 60$ & $4.13(2.07-8.27)$ & $<0.001$ & $1.13(0.19-6.53)$ & 0.90 \\
\hline Previous neoplasia & $1.43(0.66-3.12)$ & 0.37 & - & - \\
\hline$P E$ size $>1 / 3$ & $2.36(1.10-5.06)$ & 0.03 & $0.57(0.05-6.04)$ & 0.64 \\
\hline Leucocytes $\leqslant 1150\left(1 \mathrm{~mm}^{-3}\right)$ & $4.28(2.09-8.75)$ & $<0.001$ & $1.51(0.27-8.49)$ & 0.64 \\
\hline Lymphocytes > 75 (\%) & $3.34(1.64-6.83)$ & 0.001 & $0.53(0.06-5.08)$ & 0.58 \\
\hline Calprotectin $\leqslant 545\left(\mathrm{ng} \mathrm{ml}^{-1}\right)$ & $256.75(54.32-1213.61)$ & $<0.001$ & $663.14(35.37-12433.89)$ & $<0.001$ \\
\hline
\end{tabular}

Abbreviations: $\mathrm{ADA}=$ adenosine deaminase; $\mathrm{OR}=$ odds ratio, $\mathrm{Cl}=$ confidence interval

CA 15-3 (Villena et al, 2003; Liang et al, 2008). Nevertheless, we note a promising study that has found that matrix metalloproteinase (MMP)-9 also performs well in distinguishing PE of lung cancer origin from benign inflammatory patients, with sensitivity and specificity values of $80 \%$ and $100 \%$, respectively (Kremer et al, 2010).

In addition to the diagnostic parameters, logistic regression analysis corroborated that calprotectin levels are relevant to the risk of the malignant origin of the effusion. Other parameters (see Table 4) also influenced the probability of malignancy; however, the contribution of these factors was minimal compared with that of calprotectin, and these factors were not confirmed as significant predictors by multivariate analysis.

Calprotectin belongs to the S100 protein family of cytoplasmic $\mathrm{Ca}^{+2}$-binding proteins, and it has been shown to be involved in both inflammatory and neoplastic disorders (reviewed in Ghavami et al (2009). Intriguingly, its functions in cancer biology are somewhat contradictory. On one hand, it is a powerful apoptotic agent when produced by immune cells. On the other hand, calprotectin expression in cancer cells has been associated with tumour development, cancer invasion, and metastasis (Ghavami et al, 2009).

In contrast, its relationship with inflammation is clear, with a proven pro-inflammatory role in several inflammatory conditions (Cross et al, 2005; Gebhardt et al, 2006). Thus, high levels of this protein could be expected in patients with inflammatory disease, including most of the benign pathologies considered in this study (Vermeire et al, 2006; Kallel et al, 2011).

We could reasonably expect to find high levels of calprotectin in MPE because it is also involved in inflammation-associated carcinogenesis (Gebhardt et al, 2006; Ghavami et al, 2009), and supporting evidence of its expression in cancer cells has been reported in other studies (Odegaard et al, 2008; Davidson et al, 2010). We found levels ranging from $90.7-736.4 \mathrm{ng} \mathrm{ml}^{-1}$ in MPE that although clearly lower than those in BPE may not be due to a downregulation in protein expression related to malignancy. As PE is a manifestation of pleural disease, pleural fluid cannot be obtained from healthy individuals, complicating our understanding of these differences.

The higher calprotectin levels found in BPE could be attributed to the antimicrobial role of this protein. It has been proposed that massive amounts of calprotectin are released when neutrophils die as a strategy to inhibit the growth of a variety of fungal and bacterial pathogens (Santhanagopalan et al, 1995; Nisapakultorn et al, 2001). Accordingly, we found the highest levels of calprotectin in pneumonia and tuberculous PE and lower levels in other benign non-infectious aetiologies.

In a recent study, Kremer et al (2010) analysed several markers in pleural fluid from patients with lung cancer and benign inflammatory disease that were comparable to the patients in our study group. Curiously, they found that the PE concentrations of the seven biological markers analysed were lower in cancer patients. Two of those markers (MMP-2 and MMP-9) are similar to calprotectin in that they are expressed in various pathological processes, such as inflammation and cancer, and also in response to infections.

The concentration of any molecule in the body fluids is influenced by many factors, including the proximity of the secretion or the dilution of the fluid; thus, the levels of calprotectin are not necessarily the same when measured in the plasma/serum and pleural fluid. In this sense, we do not consider the finding of higher plasma calprotectin levels in invasive ovarian cancer 
compared with benign tumours (Odegaard et al, 2008) or in serum from prostate cancer patients (Hermani et al, 2005) and serum and faecal samples from colorectal carcinoma patients (Kristinsson et al, 1998; Vermeire et al, 2006; Kallel et al, 2011) to contradict our findings. Consistent with this explanation, MMP-9 and MMP2 , which are detected in lower levels in PE from lung cancer patients, have also been associated with increased tumour spread and poor prognosis in lung cancer (Kodate et al, 1997; Kremer et al, 2010) and found to be overexpressed in ovarian and breast cancer patients (Somiari et al, 2006; Zhang et al, 2011). We concur with Kremer et al (2010) that regardless of the mechanism involved, the existence of altered levels of a molecule in PE, in our case calprotectin, is of substantial clinical significance. The presence of malignant effusion implies an advanced stage and associated poor prognosis, with a median survival time of $\sim 4$ months (Neragi-Miandoab, 2006; Roberts et al, 2010). Thus, the rapid diagnosis of these patients is of great interest.

The method proposed here is based on the evaluation of the calprotectin levels in pleural fluid and could be a good complement to routine cytopathological examination. The diagnostic performance of calprotectin showed a high sensitivity and specificity, indicating a good accuracy for predicting which PE patients present a benign or a malignant underlying process. Moreover, the measurement method could be easily incorporated into routine clinical practice without any risk or discomfort to the patient.

The study presented here has some limitations. First, the number of patients is low, considering the number of aetiologies of PE included. Furthermore, the calprotectin level measurements

\section{REFERENCES}

Alemán C, Sánchez L, Alegre J, Ruiz E, Vázquez A, Soriano T, Sarrapio J, Teixidor J, Andreu J, Felip E, Armadans L, Fernández De Sevilla T (2007) Differentiating between malignant and idiopathic pleural effusions: the value of diagnostic procedures. QJM 100: 351-359

Botana-Rial M, Casado-Rey P, Leiro-Fernández V, Andrade-Olivié M, Represas-Represas C, Fernández-Villar A (2011) Validity of procalcitonin and C-reactive Protein measurement when differentiating between benign and malignant pleural effusion. Clin Lab 57: 373-378

Cross SS, Hamdy FC, Deloulme JC, Rehman I (2005) Expression of S100 proteins in normal human tissues and common cancers using tissue microarrays: S100A6, S100A8, S100A9 and S100A11 are all overexpressed in common cancers. Histopathology 46: 256-269

Davidson B, Stavnes HT, Førsund M, Berner A, Staff AC (2010) CD 105 (Endoglin) expression in breast carcinoma effusions is a marker of poor survival. The Breast 19: 493-498

Dikmen G, Dikmen E, Kara M, Sahin E, Doğan P, Ozdemir N (2003) Diagnostic implications of telomerase activity in pleural effusions. Eur Respir J 22: 422-426

Duysinx BC, Corhay JL, Hubin L, Nguyen D, Henket M, Louis R (2008) Diagnostic value of interleukine-6, transforming growth factor-beta 1 and vascular endothelial growth factor in malignant pleural effusions. Respir Med 102: 1708-1714

Gebhardt C, Németh J, Angel P, Hess J (2006) S100A8 and S100A9 in inflammation and cancer. Biochem Pharmacol 72: 1622-1631

Ghavami S, Chitayat S, Hashemi M, Eshraghi M, Chazin WJ, Halayko AJ, Kerkhoff C (2009) S100A8/A9: A Janus-faced molecule in cancer therapy and tumorgenesis. Eur J Pharmacol 625: 73-83

Gu P, Huang G, Chen Y, Zhu C, Yuan J, Sheng S (2007) Diagnostic utility of pleural fluid carcinoembryonic antigen and CYFRA 21-1 in patients with pleural effusion: a systematic review and meta-analysis. J Clin Lab Anal 21: 398-405

Heffner JE (2008) Diagnosis and management of malignant pleural effusion. Respirology 13: 5-20

Hermani A, Hess J, De Servi B, Medunjanin S, Grobholz R, Trojan L, Angel P, Mayer D (2005) Calcium-binding proteins S100A8 and S100A9 as novel diagnostic markers in human prostate cancer. Clin Cancer Res 11: 5146-5152

Hooper C, Lee YC, Maskell N (2010) Investigation of a unilateral pleural effusion in adults: British Thoracic Society Pleural Disease Guideline 2010. Thorax 65(Suppl2): ii4-ii17 were all made in the same laboratory facilities, and patients were recruited from a unique pneumology service. Thus, although the results have been statistically validated, further large-scale studies must be performed to determine whether calprotectin can be effectively used in the average clinical setting.

\section{ACKNOWLEDGEMENTS}

We are grateful to the patients who participated and made the study possible. Special thanks are given to D Ayude for critical comments and L Barcia for technical assistance. We are grateful to V Leiro, C Represas, and M Núñez (Pneumology Department, CHUVI) for their collaboration in the acquisition of samples. This research was partially supported by grants PS09-00405 and Research Intensification activity from the Fondo de Investigación Sanitaria (FIS) of the Instituto de Salud Carlos III (Spain) and funding from Xunta de Galicia and FEDER (CN 2011/024). Sonia Blanco is supported by a fellowship from the Programa Nacional de Formación de Profesorado Universitario (FPU, Ministerio de Ciencia e Innovación).

\section{Conflict of interest}

The authors declare no conflict of interest.

Supplementary Information accompanies the paper on British Journal of Cancer website (http://www.nature.com/bjc)

Kallel L, Fekih M, Boubaker J, Filali A (2011) Faecal calprotectin in inflammatory bowel diseases: review. Tunis Med 89: 425-429

Kodate M, Kasai T, Hashimoto H, Yasumoto K, Iwata Y, Manabe H (1997) Expression of MMP (gelatinase) in T1 adenocarcinoma of the lung. Pathol Int 47: 461-469

Kremer R, Best LA, Savulescu D, Gavish M, Nagler RM (2010) Pleural fluid analysis of lung cancer vs benign inflammatory disease patients. $\mathrm{Br} J$ Cancer 102: 1180-1184

Kristinsson J, Røseth A, Fagerhol MK, Aadeland E, Schjønsby H, Børmer OP, Raknerud N, Nygaard K (1998) Fecal calprotectin concentration in patients with colorectal carcinoma. Dis Colon Rectum 41: 316-321

Kristinsson J, Røseth A, Fagerhol MK, Aadland E, Schjønsby H, Børmer OP, Raknerud N, Nygaard K (1998) Fecal calprotectin concentration in patients with colorectal carcinoma. Dis colon rectum 41: 316-321

Liang QL, Shi HZ, Qin XJ, Liang XD, Jiang J, Yang HB (2008) Diagnostic accuracy of tumour markers for malignant pleural effusion: a metaanalysis. Thorax 63: 35-41

Light RW (2006) The undiagnosed pleural effusion. Clin Chest Med 27: 309-319

Neragi-Miandoab S (2006) Malignant pleural effusion, current and evolving approaches for its diagnosis and management. Lung Cancer 54: 1-9

Nisapakultorn K, Ross KF, Herzberg MC (2001) Calprotectin expression inhibits bacterial binding to mucosal epithelial cells. Infect Immun 69: 3692-3696

Odegaard E, Davidson B, Engh V, Onsrud M, Staff AC (2008) Assessment of endoglin and calprotectin as potential biomarkers in ovarian carcinoma and borderline tumors of the ovary. Am J Obstet Gynecol 199: 533 e1-8

Porcel JM, Vives M, Esquerda A, Salud A, Pérez B, Rodríguez-Panadero F (2004) Use a panel of tumor markers (carcinoembryonic antigen, cancer antigen 125, carbohydrate antigen 15-3, and cytokeratin 19 fragments) in pleural fluid for the differential diagnosis of benign and malignant Effusions. Chest 126: 1757-1763

Roberts ME, Neville E, Berrisford RG, Antunes G, Ali NJ, Pleural BTS, Disease Guideline Group (2010) Management of a malignant pleural effusion: British Thoracic Society Pleural Disease Guideline 2010. Thorax 65(Suppl2): ii32-ii40

Rodríguez-Piñeiro AM, Blanco-Prieto S, Sánchez-Otero N, RodríguezBerrocal FJ, de la Cadena MP (2010) On the identification of biomarkers for non-small cell lung cancer in serum and pleural effusion. J Proteomics 73: $1511-1522$ 
Santhanagopalan V, Hahn BL, Dunn BE, Weissner JH, Sohnle PG (1995) Antimicrobial activity of calprotectin isolated from human empyema fluid supernatants. Clin Immunol Immunopathol 76: 285-290

Somiari SB, Somiari RI, Heckman CM, Olsen CH, Jordan RM, Russell SJ, Shriver CD (2006) Circulating MMP2 and MMP9 in breast cancer-Potential role in classification of patients into low risk, high risk, benign disease and breast cancer categories. Int J Cancer 119: 1403-1411

Sriram KB, Relan V, Clarke BE, Duhig EE, Yang IA, Bowman RV, Lee YC, Fong KM (2011) Diagnostic molecular biomarkers for malignant pleural effusions. Future Oncol 7: 737-752

Vermeire S, Van Assche G, Rutgeerts P (2006) Laboratory markers in IBD: useful, magic, or unnecessary toys? Gut 55: 426-431
Villena Garrido V, Ferrer Sancho J, Hernández Blasco L, de Pablo Gafas A, Pérez Rodríguez E, Rodríguez Panadero F, Romero Candeira S, Salvatierra Velázquez A, Valdés Cuadrado L, Area de Tecnicas y Trasplantes. SEPAR (2006) Diagnosis and treatment of pleural effusion. Arch Bronconeumol 42: 349-372

Villena V, López-Encuentra A, Echave-Sustaeta J, Martín-Escribano P, Ortuño-de-Solo B, Estenoz-Alfaro J (2003) Diagnostic value of CA 549 in pleural fluid. Comparison with CEA, CA 15.3 and CA 72.4. Lung Cancer 40: 289-294

Zhang W, Yang HC, Wang Q, Yang ZJ, Chen H, Wang SM, Pan ZM, Tang BJ, Li QQ, Li L (2011) Clinical value of combined detection of serum matrix metalloproteinase-9, heparanase, and cathepsin for determining ovarian cancer invasion and metastasis. Anticancer Res 31: 3423-3428

This work is published under the standard license to publish agreement. After 12 months the work will become freely available and the license terms will switch to a Creative Commons Attribution-NonCommercial-Share Alike 3.0 Unported License. 